Article

\title{
Making Smart and Sustainable Infrastructure Projects Viable: Private Choices, Public Support, and Systems Constraints
}

\author{
Douglas Noonan ${ }^{1, *}$, Shan Zhou $^{2}$ and Robert Kirkman ${ }^{2}$ \\ ${ }^{1}$ School of Public and Environmental Affairs, Indiana University-Purdue University Indianapolis, Indianapolis, IN 46202, \\ USA; E-Mail: noonand@iupui.edu \\ 2 School of Public Policy, Georgia Institute of Technology, Atlanta, GA 30332, USA; E-Mails: zhoushanbnu@gmail.com (S.Z.), \\ robert.kirkman@gatech.edu (R.K.) \\ * Corresponding author
}

Submitted: 29 April 2017 | Accepted: 23 August 2017| Published: 8 September 2017

\begin{abstract}
Sustainable cities will require major infrastructure investments coupled with widespread behavioral change. Examples of smart, green technologies abound, but evidence for actual use lags. This partly owes to the tension between public support and private choices: individuals thinking as members of the public may see solutions as smart for the city, but thinking of their private interests may see those same solutions as not smart for themselves. This also owes to the disconnect between private and public choices, on the one hand, and the workings of complex systems, on the other. Even if public and private interests align, existing built environment systems may resist change. This article examines public perception and use of the Atlanta BeltLine, a pioneering sustainability initiative to transform the auto-dependent city into a greener, denser city. Analyzing a general public survey reveals widespread support for the BeltLine alongside reticence from residents to change their commute or greenspace use. The findings also show that drivers of public support and prospective use of the Beltline differ. Public support may be insufficient if individual use decisions do not follow. Yet, private adoption decisions may not follow until and unless the systems in which they are embedded are already changing.
\end{abstract}

\section{Keywords}

behavioral changes; green space; public perception; public transit; smart solutions; urban infrastructure;

urban sustainability

Issue

This article is part of the issue "Smart Solutions for Sustainable Cities", edited by Tom Sanchez (Virginia Tech, USA), Ralph Hall (Virginia Tech, USA) and Nader Afzalan (Redlands University, USA).

(C) 2017 by the authors; licensee Cogitatio (Lisbon, Portugal). This article is licensed under a Creative Commons Attribution 4.0 International License (CC BY).

\section{Introduction}

Urban population and areas are expanding rapidly in the past few decades (Angel, Parent, Civco, Blei, \& Potere, 2011). Due to their significant influence on both regional and global environment (Alberti, 1996; Grimm et al., 2008), sustainability issues at the city level have gained increasing importance in the planning literature. Cities can promote sustainable development in several fields, such as housing, energy, employment, and environmental quality (Camagni, Capello, \& Nijkamp, 1998).

Infrastructure and technologies are a key dimension in urban sustainability (Alberti, 1996). Serving as "ma- terial mediators between nature and the city" (Kaika \& Swyngedouw, 2000), urban infrastructure systems (UIS) share many key common characteristics, such as large social investments in facilities, networked physical components, and long economic return period (Nielsen \& Elle, 2000). Once in place, urban infrastructure is difficult to reverse, and its longevity often leads to a path dependency with regard to energy use and climate change adaptation strategies (Seto \& Shepherd, 2009). From an engineering perspective, sustainable UIS means that the energy and materials flow through the system and the residuals generated by the system should be minimized to the extent possible (Sahely, Kennedy, \& Adams, 2005). 
Recent research explores the prospects for innovative UIS to promote sustainable urban development. For instance, Kramers, Höjer, Lövehagen and Wangel (2014) discuss the potential to use information and communication technology solutions for energy conservation in cities. Borén et al. (2017) explored the Swedish GreenCharge Southeast project as an example of sustainable urban transport systems.

In assessing the sustainability of UIS, researchers have particularly emphasized its social dimension: innovative technology leads to sustainable regime change when it is actually used and competitive (Kemp, Schot, \& Hoogma, 1998). Sahely et al. (2005) propose evaluating UIS with criteria including public awareness, participation, and acceptance of UIS. Social factors like user groups and providers of infrastructure services are also important in Monstadt's (2009) urban infrastructure regime analysis. Another strand of literature in urban sustainability follows Hughes (1987) and adopts the "systems" perspective. It considers urban infrastructure as socio-technical systems co-produced by technical apparatus and social components (i.e., organizational, economic and political actors and structures) (Fiksel, 2006; Hodson, Marvin, Robinson, \& Swilling, 2012). Cities worldwide are seeking to develop change in the socio-technical organization of their infrastructure networks, which can be characterized as "systemic transitions" (Hodson \& Marvin, 2010).

While sustainable and smart cities are conceptualized with multiple dimensions of technology, people, and institutions (Camagni et al., 1998; Nam \& Pardo, 2011), the complex interrelationship among technological systems, private behavior, and public choice in bringing about sustainability has yet to be explored in depth. To add more empirical evidence on some of these relationships, this paper uses the Atlanta BeltLine project as an empirical example to understand the social and systemic dimension of UIS.

The adoption and implementation of UIS for sustainable cities involves both collective decisions and private actions. To bring about changes in the social and technological systems that make up the city requires public decisions and public investment. Long-term success of those changes depends critically on the behavior of private individuals, often acting as consumers. If the two are not aligned, if individual behavior does not fall in line with the intentions behind public choices, even the best crafted public project may fail: you may build it, but they will not come.

One source of this misalignment can be found in the tension between public support and private choices: individuals thinking as members of the public may see solutions as smart for the city but, thinking of their private interests, may see those same solutions as not smart for themselves. Accounting for the behavior of private individuals, especially the possibility of a kind of decentralized resistance to public policy, is by no means simple. At one level, insight from the environmental psychology lit- erature indicates that apparently pro-environmental attitudes may not be reflected in behavioral changes (Kollmuss \& Agyeman, 2002). For sustainable urban projects, individuals' ex ante political support and ex post use may diverge for various reasons. Designing UIS with both strong public support initially and pro-environmental behaviors/utilization remains a challenge for smart solutions in urban development.

Another source of misalignment, and one much more difficult to detect and to alter, is the disconnect between private and public choices, on the one hand, and the workings of complex systems, on the other. Even if private interests and public support were to align in favor of a smart infrastructure project, the existing systems of the built environment may resist any effort to bring about change, or deflect such efforts in unexpected directions.

More deeply, the behavior of individuals and the values, attitudes, and beliefs that shape that behavior are in turn shaped by the social and technological systems within which individuals live and pursue their various projects. These constraints can work in two directions: from the outside in and from the inside out (Kirkman, Noonan, \& Dunn, 2012). From the outside, living within systems provides opportunities for and imposes constraints on individual conduct; it creates paths of least resistance. From the inside, systems also create and impose structures of meaning and value that shape what individuals imagine and what they strive for.

Take as an example the system of transportation based on ownership and use of private automobiles. As a complex technological system, it includes social and technical components (Hughes, 1994): cars, roads, gas stations, oil refineries, licensing bureaus, highway departments, oil cartels, and so on and on. Among the social components are ways of making sense of the world that may limit in advance the capacity of individuals to think and choose freely. This aligns with what Bijker (1995) calls a "technological frame".

In this paper, we consider urban residents, their perception and behaviors as a critical component in the sustainable urban transformation process. We conducted a novel survey of the general public in order to better understand the interplay of public support, behavioral change, and systemic change in sustainable urban initiatives. We argue that public decisions leading to changes in the technical components of urban systems cannot, in themselves, succeed in bringing about more sustainable cities. Instead, public processes must somehow grapple with the resistance likely to be offered by private behavior as it is conditioned by systems.

The empirical case we study is the BeltLine project in Atlanta, United States (see Figure 1 for a map of the project and the city). The city of Atlanta has a typical American urban form, characterized by auto-dependence and urban sprawl. Like many other metropolises in the world, Atlanta is in dire need of a transformation for sustainability. The BeltLine project represents a major effort to transform the auto-dependent city into a greener, 


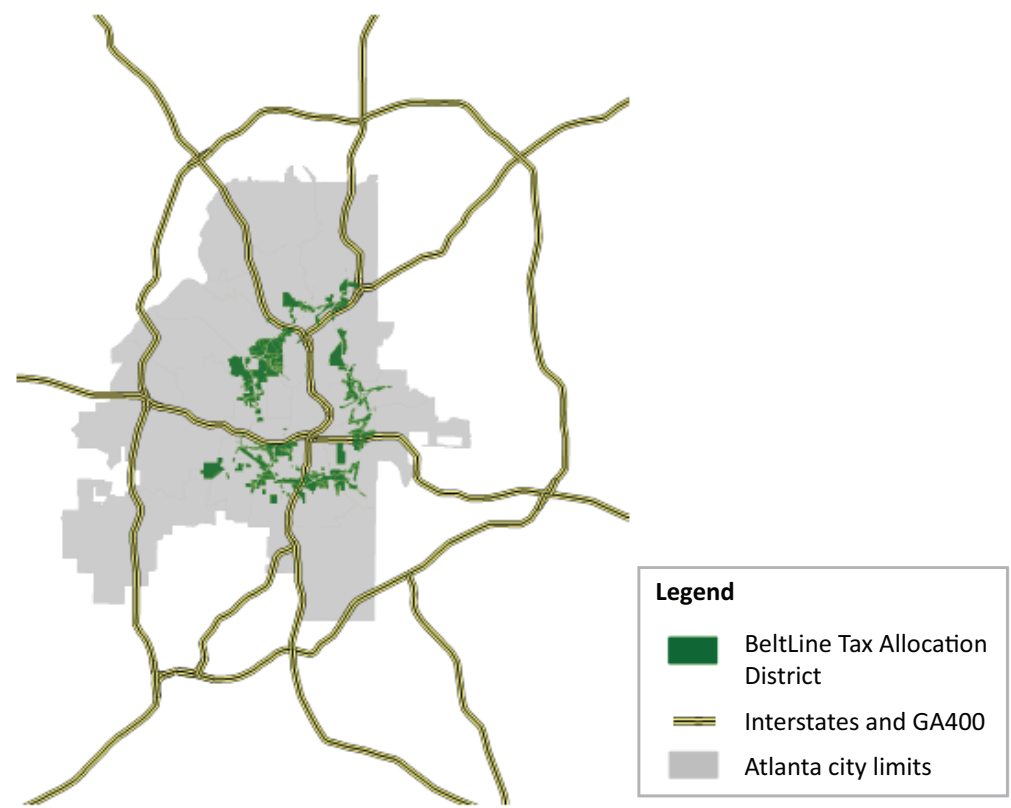

Figure 1. Map of Atlanta BeltLine project.

denser city with more public transit and affordable housing. As a pioneering urban sustainability project in the U.S., the BeltLine offers an ideal case to study whether or not public support and willingness to use of the urban sustainable projects align well with each other. This analysis also sheds light on the effective design and implementation of smart solutions for sustainable cities.

This paper is organized as follows. The next section provides an overview of the Atlanta BeltLine project, including its history and vision. The third section discusses the people and built infrastructure for sustainable cities in the context of the BeltLine project. Then we use survey data to understand how the public perceives and intends to use the Beltline parks and transit systems. To explain the discrepancy between public support and individual use of the project, ordered logistic regression models are estimated. The analysis confirms the widespread public support while also revealing substantial resistance on the part of residents to change their commute or use of greenspace. The findings show that drivers of public support and prospective use of the BeltLine project differ. We conclude this paper with a discussion of implications for sustainable urban planning.

\section{The City of Atlanta and the BeltLine Project}

Metropolitan Atlanta is the eighth largest metropolitan area in the U.S, with a population of 5.7 million in 2015 (U.S. Census Bureau, 2016). Atlanta has actively engaged itself in the global paradigm shift towards sustainable cities. One of the city's key efforts is the Atlanta BeltLine project, which promises to transform the city from what is arguably the southeastern United States' poster child for urban sprawl into a smarter, denser, greener, healthier, more mixed use, and more prosperous metropolis (Alex Garvin \& Associates, Inc., 2004). City planners and project designers claim "the Atlanta BeltLine will provide the framework for smart growth, enhancing the city's sustainability and economic vitality" (Atlanta BeltLine, 2017a). The magnitude of the BeltLine's promise, if not the reality, is hard to overstate. Press conferences and promotional materials echo the "transformational" rhetoric (Atlanta BeltLine, 2011; Kirkman et al., 2012). The project remains a work-in-progress today, and time will tell how it evolves. Early indications, with seven new parks, over 2,000 affordable workforce housing units, and 11 miles of trails since 2008, are promising (Atlanta BeltLine, 2017b).

The BeltLine concept, first proposed by Ryan Gravel in his 1999 master's thesis at the Georgia Institute of Technology, involves converting a 22-mile ring of largely abandoned rail lines around the Atlanta core into a greenbelt with a light rail loop. Sustainability and transitoriented development (TOD) are central to the design, planning, and implementation of the project. Table 1 summarizes the BeltLine program elements and how they promote sustainability. In particular, brownfields will be replaced with new trails and greenspace. The BeltLine regional transit and the Atlanta Streetcar system will connect with the existing urban transit systems (Atlanta BeltLine, 2017c). The BeltLine affordable housing element promotes sustainable growth around the Atlanta BeltLine to increase access to mobility, jobs, and quality of life amenities (Atlanta BeltLine, 2013a). The project's goals encompass 1,300 acres of new or expanded parks, connected via 33 miles of continuous trails, and linking the 22-mile transit system to the regional transit network that would also result in over 30,000 new permanent jobs and 5,600 new affordable housing units (Atlanta BeltLine Tax Allocation District Advisory Committee, 2012). The combination of environmentally friendly transportation, economic development, walkability, and 
Table 1. Atlanta BeltLine program elements.

\begin{tabular}{|c|c|c|c|c|c|c|}
\hline \multirow{2}{*}{$\begin{array}{l}\text { Program } \\
\text { Elements }\end{array}$} & \multirow[t]{2}{*}{ Details } & \multirow{2}{*}{$\begin{array}{l}\text { Expected } \\
\text { beneficiary }\end{array}$} & \multirow{2}{*}{$\begin{array}{l}\text { How the public } \\
\text { would be engaged }\end{array}$} & \multicolumn{3}{|c|}{ How they promote sustainability? } \\
\hline & & & & Ecological & Social & Economic \\
\hline Parks & $\begin{array}{l}1300 \text { acres of new } \\
\text { greenspace; } 700 \\
\text { acres of renovated } \\
\text { greenspace }\end{array}$ & $\begin{array}{l}\text { All citizens in the } \\
\text { metro Atlanta } \\
\text { region and visitors }\end{array}$ & $\begin{array}{l}\text { Use park amenities } \\
\text { and programs }\end{array}$ & $\checkmark$ & $\checkmark$ & $\checkmark$ \\
\hline Trails & 33 miles of trails & $\begin{array}{l}\text { All citizens in the } \\
\text { metro Atlanta } \\
\text { region and visitors }\end{array}$ & $\begin{array}{l}\text { Use trails to } \\
\text { promote walking, } \\
\text { jogging, biking and } \\
\text { living along the } \\
\text { BeltLine }\end{array}$ & $\checkmark$ & $\checkmark$ & \\
\hline $\begin{array}{l}\text { Affordable } \\
\text { Housing }\end{array}$ & $\begin{array}{l}5,600 \text { affordable } \\
\text { housing units }\end{array}$ & $\begin{array}{l}\text { Homebuyers and } \\
\text { renter who wish } \\
\text { to live in and } \\
\text { around the } \\
\text { BeltLine, } \\
\text { developers and } \\
\text { businesses }\end{array}$ & $\begin{array}{l}\text { Take advantage of } \\
\text { the various } \\
\text { benefits, such as tax } \\
\text { exemptions for } \\
\text { homeowners, down } \\
\text { payment assistance } \\
\text { program and } \\
\text { owner-occupied } \\
\text { rehabilitation } \\
\text { funding, etc. }\end{array}$ & & $\checkmark$ & $\checkmark$ \\
\hline Transit & $\begin{array}{l}\text { A streetcar light- } \\
\text { rail transit system }\end{array}$ & $\begin{array}{l}\text { All citizens in the } \\
\text { metro Atlanta } \\
\text { region and visitors }\end{array}$ & $\begin{array}{l}\text { Use MARTA, the } \\
\text { new Atlanta } \\
\text { Streetcar and other } \\
\text { public transit }\end{array}$ & $\checkmark$ & $\checkmark$ & $\checkmark$ \\
\hline $\begin{array}{l}\text { Economic } \\
\text { Development }\end{array}$ & $\begin{array}{l}\text { Revitalizing } 45 \\
\text { BeltLine } \\
\text { neighborhoods; } \\
\text { creating } 30,000 \\
\text { permanent jobs } \\
\text { and } 48,000 \text { one- } \\
\text { year construction } \\
\text { jobs }\end{array}$ & $\begin{array}{l}\text { All citizens in the } \\
\text { metro Atlanta } \\
\text { region, property } \\
\text { owners, } \\
\text { employees and } \\
\text { visitors }\end{array}$ & $\begin{array}{l}\text { Spend within the } \\
\text { BeltLine TAD; invest } \\
\text { in retail, office and } \\
\text { other development } \\
\text { activities along the } \\
\text { BeltLine }\end{array}$ & & $\checkmark$ & $\checkmark$ \\
\hline Urban Farm & $\begin{array}{l}\text { Aluma Farm } \\
\text { at Aluma Park and } \\
\text { more }\end{array}$ & $\begin{array}{l}\text { Farmers and urban } \\
\text { neighborhoods }\end{array}$ & $\begin{array}{l}\text { Purchase locally } \\
\text { grown produce }\end{array}$ & $\checkmark$ & $\checkmark$ & $\checkmark$ \\
\hline
\end{tabular}

Source: Atlanta BeltLine (2013a).

social equity makes the BeltLine a major effort for urban sustainable development.

Despite the excitement and widespread political support, the BeltLine proposal took the better part of a decade to wend its way through the political process before the first segments opened (see Table 2 for highlights of the timeline). Some initial hiccups occurred, such as a hold-out slowing land acquisition and a Georgia State Supreme Court ruling that led to amending the state constitution to allow the BeltLine to be funding through Tax Increment Financing (TIF) (Sherman v. Atlanta Independent School System et al., 2013). In light of the sticky nature of entrenched interests and of the equilibrium urban form in Atlanta-and the need to amend the state constitution-breaking ground on such a major, transformational project just a decade after a master's thesis was written is a remarkable achievement in its own right.

\section{People and Built Infrastructure for Sustainable Cities}

In 2014, the Atlanta BeltLine received the EPA's National Award for Smart Growth Achievement. Smart growth refers to strategies to protect health and the environment as well as improve communities' attractiveness, economic strength, and social diversity (Environmental Protection Agency, 2017). The Atlanta BeltLine project is intended to transform the "dominant urban form" characterized by sprawl, automobile dependency, a hollowed 
Table 2. BeltLine historical milestones.

\begin{tabular}{|c|c|}
\hline 2004 & Grassroots support grows, Emerald Necklace (Garving \& Associates, 2004) study commissioned. \\
\hline 2005 & Mayor Franklin creates the BeltLine Partnership; BeltLine Redevelopment Plan and the TAD are approved. \\
\hline 2006 & Atlanta BeltLine, Inc. created to oversee implementation; more land acquired. \\
\hline 2007 & $\begin{array}{l}\text { MARTA approves light rail transit on BeltLine. BeltLine Zoning Overlay District adopted. BeltLine acquires 4.5-mile } \\
\text { stretch of loop from hold-out developer. }\end{array}$ \\
\hline 2008 & Effort of nonprofits lead to first trail segment opening. First TAD bonds issued. \\
\hline 2010 & Construction on trails and parks continue, more trails open. \\
\hline 2011 & More parks, trails open. Trails host arts and running events. \\
\hline 2012 & Master planning process concludes. Transportation Special Purpose Local Option Sales Tax (TSPLOST) vote fails. \\
\hline 2013 & $\begin{array}{l}\text { Leadership change at Atlanta BeltLine, Inc. after finance scandal. The City of Atlanta was awarded an \$18 million } \\
\text { grant from the U.S. Department of Transportation to develop the Atlanta BeltLine. }\end{array}$ \\
\hline 2014 & More trails open and an art exhibit was hosted. A tour bus program was implemented. \\
\hline 2015 & $\begin{array}{l}\text { More trails and skateparks open, and affordable housing programs were developed. Senate Bill } 4 \text { was passed to } \\
\text { allow public-private partnerships to fund transportation. The Atlanta Streetcar System Plan was adopted by the } \\
\text { City Council. }\end{array}$ \\
\hline 2016 & $\begin{array}{l}\text { City of Atlanta voters passed the TSPLOST and MARTA sales taxes, which will finance land purchases and the } \\
\text { constructions of transit network of the BeltLine. }\end{array}$ \\
\hline 2017 & $\begin{array}{l}\text { Seven of the Atlanta BeltLine parks are open to the public. More than 2,000 affordable workforce housing units } \\
\text { were created. }\end{array}$ \\
\hline
\end{tabular}

out downtown core, and other ills common to large U.S. cities (Kirkman et al., 2012). This model is widely understood to be unsustainable in the long run, requiring evergrowing inputs of energy and other resources while also fostering social inequity and other ills.

By seeking to catalyze a more structural change towards a sustainable city, the BeltLine aims to not just undo the old pattern, but also institute a new pattern. It promises a new vision that emphasizes cohesive community, urban connectivity, and smart growth. As an integrated approach to land use, transportation, and economic development, the Beltline will expand unprecedentedly the city's park land, public spaces, regional transit and transportation networks (Atlanta BeltLine, 2017c). Note that this entails not only a change in technical aspects of systems, the arrangements of physical objects and the flows of energy and matter through them. It also entails a change in social forms and norms, and in the values and visions of individuals living within the system. An explicit part of the vision of advocates for the Beltline is not only a transformation of how people behave, but in fostering a new kind of civility in a distinctly new urban context (Atlanta Development Authority, 2006). As the most ambitious and comprehensive revitalization effort ever undertaken in the City, "you might say that the battle over the BeltLine is a matter of life or death" for Atlanta (Pendergrast, 2017, p. x).

The key challenge here is that the dominant urban form of the last century has been particularly hard to change (Wheeler, 2003), although recent development of information technologies has been shown to affect urban commuting behaviors (Kumar, 1990). Such is the nature of equilibria that they are often stable equilibria, but the dominant urban form of the 20th century may be especially "sticky": efforts toward change may be deflected or pulled back toward the established equilibrium, either through the brute resistance of physical infrastructure, the persistence of values and attitudes shaped by the dominant technical form, or both. As a "sociotechnical ensemble" or an interdependent network of urban systems (transport, land use, governance, industry, etc.) (Bijker, 1995), the dominant urban form in the U.S. is proving to be one that many reformers and visionaries are finding we are "stuck" with (Kirkman et al., 2012).

As noted, the role of private behavior and the values and attitudes from which it springs has received far less attention in the urban planning literature compared to the technical and policy aspects of sustainable cities (see for instance Bulkeley \& Betsill (2005) for a detailed policy discussion). Residents of the city not only play a critical role in the governance and management of sustainable urban project (Drazkiewicz, Challies, \& Newig, 2015), they are also expected to become active users of the various features of sustainable cities (Nevens, Frantzeskaki, Gorissen, \& Loorbach, 2013). For many initiatives for sustainable cities (e.g., energy efficiency [Stieninger, 2013], information technology [Khansari, Mostashari, \& Mansouri, 2014]), changing human behavior through urban 
planning efforts has proven to be at least as important as technological advancement. This highlights the need to understand how the general public perceives and responds to smarter urban infrastructure, and how perceptions and responses are conditioned by existing systems.

The literature shows mixed evidence on the relationship between technology and behavioral changes. Some conclude a positive role of technology in driving behavior changes. For instance, Durand, Andalib, Dunton, Wolch, \& Pentz (2011) find that smart growth features-such as diverse housing types, mixed land use, compact development, and open space-correlate with increased levels of physical activity and walking. Nasri and Zhang (2014) find that TOD areas in Washington, D.C. and Baltimore tend to reduce residents' vehicle miles traveled by around $38 \%$ and $21 \%$ respectively. Others show the impact of technology on behavior change to be insignificant or even negative. Energy efficiency technology is an often-cited example that might lead to increased energy consumption due to rebound effects (Herring \& Roy, 2007). There is also evidence that people who believe technological solutions will solve environmental problems were less likely to engage in pro-environmental behaviors (Gigliotti, 1992).

Of particular interest in the wide array of studies of resident responses to UIS changes is the literature examining utilization of new public transit projects. Proximity to stations matters (Cervero, 1993), but transit ridership depends on other aspects of urban form. Residential and employment densities around transit stations, the degree of mixed land use (Tumlin, Millard-Ball, Zucker, \& Siegman, 2003), and small block size (Arrington \& Cervero, 2008) matter as well. Rail transit ridership in New York City and Hong Kong is influenced by land use, station characteristics, socio-economic and demographic characteristics, and inter-modal coordination among different public transportation modes (Loo, Chen, \& Chan, 2010). Further supporting the multidimensionality of factors influencing transit utilization by residents, Pucher (1988) and Nasri and Zhang (2012) identify a supportive urban development throughout the larger metropolitan area as impacting transit utilization. Transit usage clearly depends on the broader, complex technological system of the city as well as individual characteristics.

To better understand the prospect of urban infrastructure promoting sustainability, this study examines public perception of and willingness to use the Beltline project by analyzing survey responses from urban residents. This independent survey sheds light on how the public sees the city's challenges, how they perceive and intend to use the project, and what factors explain the two stages. The results confirm widespread support for the project, but they also reveal some undercurrents that dim the prospects for sustainable urban transformation. This study has important implications for other smart city initiatives and helps identify the obstacles that exist for cities using major capital investments to promote sustainable behavioral changes.

\section{Analysis of Survey Responses: What the BeltLine Means to Atlantans}

In this section, we evaluate public perception and behavioral changes that are likely to follow from the BeltLine project. Based on results of background interviews, focus groups, and pilot surveys, we designed and administered an online survey in the summer of 2009. A sample of adults in the Atlanta metropolitan area was drawn randomly from Survey Sampling International's large online panel, with $60 \%$ from within the City of Atlanta (see Cavallaro (2012) for more details on the online panel's characteristics). Selected panelists were contacted via an email invitation to an online survey about "housing, green space, and transportation" that took, on average, nine minutes to complete. A total of 946 respondents completed this 37-question survey between 16-29 June 2009 about their attitudes toward the city, their views on the Beltline, and demographics. When comparing with Atlanta metro-area demographics, the sample appears representative for many variables, such as age, income, car ownership, house tenure, and household size. The sample does appear to have shorter commutes, less tendency to move and higher educational attainment. These differences are likely largely accounted for by our oversampling of City-of-Atlanta residents, and the inclusion of those working part time or working at home in our sample. Kirkman et al. (2012) provide more details on this survey.

Descriptive statistics from survey responses are summarized in Table 3. The results show that Atlantans tend to see the City as a typical American urban form characterized by high automobile dependence and low-density urban sprawl. Over three fourths of people think Atlanta is too automobile dependent, although people do not see Atlanta as particularly lacking greenspace (nearly half respondents agree Atlanta is a very green city). Almost $30 \%$ of respondents think that traffic is a problem in Atlanta because of too few alternatives to driving, $21 \%$ blame dense population in the city, and $18 \%$ think too few, badly designed or poorly maintained roads are the main causes. The public is generally pessimistic about future quality of urban life. Most Atlantans (74\%) believe that mobility will worsen over the next five years, and $52 \%$ of respondents think Atlanta's quality of life will decline in that same period (while just $14 \%$ expect improvements). When faced with a choice between an Atlanta in 2060 that looks like it does today and one with more density, transit, and congestion, respondents favored the New York City version of future three times more often than those preferring the status quo. Although Atlantans hope that the city as a whole evolves substantially, most of them prefer that their neighborhood not change: $64 \%$ of respondents indicate that they hoped their neighborhood would stay the same after they moved there.

The transformative potential of the BeltLine proposal seems appealing to the Atlanta public. Results show strong support for both the BeltLine and its goals. About 
Table 3. Descriptive statistics from survey responses.

\begin{tabular}{|c|c|c|c|c|}
\hline Variable & Mean & Std. Dev. & Min & Max \\
\hline Atlanta is too auto-dependent ( $1=$ disagree strongly; $7=$ agree strongly) & 5.6 & 1.7 & 1 & 7 \\
\hline Atlanta is a very green city ( $1=$ disagree strongly; $7=$ agree strongly) & 4.3 & 1.7 & 1 & 7 \\
\hline How will Atlanta's quality of life change in 5 years $(-1=$ worsen, $1=$ improve) & -0.4 & 0.7 & -1 & 1 \\
\hline How will mobility in Atlanta change in 5 years $(-1=$ worsen, $1=$ improve) & -0.7 & 0.6 & -1 & 1 \\
\hline $\begin{array}{l}\text { Prefer a } 2060 \text { Atlanta that looks like it does today }(=-1) \text { or an Atlanta with } \\
\text { higher density and housing costs, and more transit, congestion and parks }(=1)\end{array}$ & 0.4 & 0.8 & -1 & 1 \\
\hline $\begin{array}{l}\text { How familiar are you with the BeltLine? ( } 1=\text { not heard of it; } 2=\text { heard of it; } \\
3=\text { know some details; } 4=\text { very familiar) }\end{array}$ & 2.2 & 1.0 & 1 & 4 \\
\hline $\begin{array}{l}\text { The BeltLine is definitely bad }(-2) \text {, more bad than good }(-1) \text {, uncertain }(0) \text {, } \\
\text { more good than bad (1), or definitely good }(2)\end{array}$ & 1.0 & 1.0 & -2 & 2 \\
\hline $\begin{array}{l}\text { Others think the BeltLine is a bad idea }(-1) \text {, are evenly divided }(0) \text {, or think } \\
\text { the BeltLine is a good idea ( } 1 \text { ) }\end{array}$ & 0.3 & 0.7 & -1 & 1 \\
\hline $\begin{array}{l}\text { I would use BeltLine parks several times per week (3), per month (2), } \\
\text { per year (1), or never (0) }\end{array}$ & 1.0 & 0.9 & 0 & 3 \\
\hline $\begin{array}{l}\text { I would use BeltLine transit several times per week (3), per month (2), } \\
\text { per year (1), or never (0) }\end{array}$ & 1.0 & 1.0 & 0 & 3 \\
\hline Many other will use BeltLine parks ( $0=\mathrm{few})$ & 0.9 & 0.3 & 0 & 1 \\
\hline Many other will use BeltLine transits ( $0=\mathrm{few})$ & 0.8 & 0.4 & 0 & 1 \\
\hline Many other will relocate to the BeltLine $(0=\mathrm{few})$ & 0.6 & 0.5 & 0 & 1 \\
\hline $\begin{array}{l}\text { BeltLine will fall far short }(-2) \text {, be smaller }(-1) \text {, be as large }(1) \text {, or } \\
\text { be larger }(2) \text { than planned }\end{array}$ & 0.1 & 1.5 & -2 & 2 \\
\hline BeltLine will transform Atlanta ( $0=$ no, $1=$ doubtful, $2=$ maybe, $3=$ definitely) & 2.0 & 0.8 & 0 & 3 \\
\hline $\begin{array}{l}\text { When I moved, I hoped my neighborhood would change }(-1) \text {, } \\
\text { stay the same (0), would not change (1) }\end{array}$ & 0.5 & 0.7 & -1 & 1 \\
\hline Commute mode $(1=\mid$ drive alone $)$ & 0.5 & 0.5 & 0 & 1 \\
\hline $\begin{array}{l}\text { Park use frequency }(0=\text { never, } 1=\text { less than yearly, } 2=\text { at least once per year, } \\
3=\text { at least once per month, } 4=\text { once per week or more) }\end{array}$ & 2.2 & 1.2 & 0 & 4 \\
\hline Education (years) & $15-2$ & $2-3$ & 10 & 19 \\
\hline Age & 49.4 & 13.8 & 21 & 75 \\
\hline Household income (in \$, logged) & 10.9 & 0.7 & 9.6 & 12.2 \\
\hline Map (shown map=1) & 0.5 & 0.5 & 0 & 1 \\
\hline Distance (to BeltLine, in km, logged) & 2.4 & 1.3 & -2.9 & 4.1 \\
\hline
\end{tabular}

three-fourths of respondents indicated that it was a good idea and it would transform Atlanta. Such widespread public approval reflects how the project appeals to a broad array of interests. Mostly, they liked the transit, neighborhood revitalization, and brownfield redevelopment aspects of the project (Figure 2). These BeltLine's promises aligned well with Atlanta's major challenges identified by respondents in the survey. Support for density, workforce housing, or other aspects was weaker. The weaker support for density is unsurprising in that density does not play a statistically significant role in metropolitan-level happiness (Florida, Mellander, \&
Rentfrow, 2013). However, this contrasts with Atlantans' preference for the high-density version of the future.

Despite the strong support for the project, probing further raises some issues. Most respondents do not intend to use the BeltLine much for transit or for its parks and trails: only a third of respondents indicated that they expect to use the BeltLine at least several times per month, while two in three respondents would rarely, if ever, use the project's transit or parks (Table 4). In being more likely to support transit than use it, Atlantans may resemble those in other US cities. Atlantans see themselves not using the BeltLine transit more frequently 


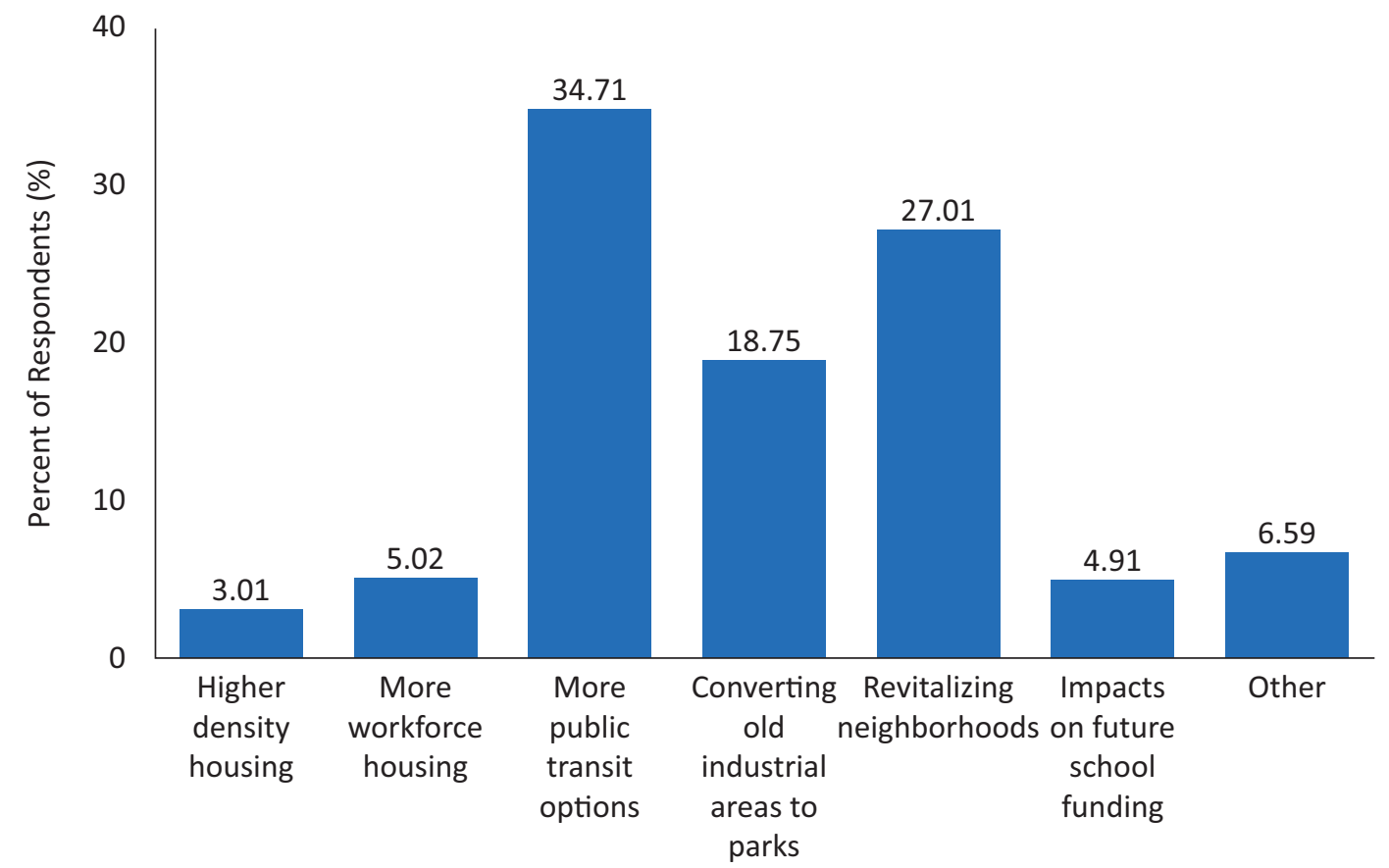

Figure 2. Best part of the BeltLine identified by respondents.

mainly because it won't go where they want (38\%) and it is too far out of their way (36\%). Uncertainty about the parks' location (30\%) and long distance from the parks (36\%) keep most respondents from using the BeltLine parks and trails more often. When asked about reasons why others might not use it, respondents recognized that most Atlantans like their community too much to move and like their cars too much to ditch them in favor of transit.

People are optimistic that others will use the parks and transit, but just not them. Among those who had guesses, Atlantans predicting "many others" will ride BeltLine transit or use its parks outnumbered those predicting to "few others" by a 5:1 margin. 50\% more re- spondents expect "many people will move to be closer to the BeltLine" than expect few will. If everyone thinks others will use the BeltLine but just not themselves, then it suggests the project might not catalyze the behavioral change it seeks.

The results of chi-square tests for independence show that prospective use of the Belthine transit and parks are not independent of public support. BeltLine supporters are more likely to say they will use Beltline transit or parks than skeptics, although the percentages are still low. Just $34.6 \%$ and $24.8 \%$ of Beltline supporters think that they will use Beltline transit and parks at least several times per month, respectively, compared to $7.7 \%$ and $4.8 \%$ of BeltLine skeptics ${ }^{1}$ (see Table 4 ). BeltLine sup-

Table 4. Summary of public support and prospective use of the BeltLine (\% of survey respondents).

\begin{tabular}{|c|c|c|c|c|c|c|c|}
\hline & & & & Prospe & e Use & & \\
\hline & & & Transit & & & Park & \\
\hline an idea is the $B$ & ine?) & & & Many & & & Many \\
\hline & & $\begin{array}{l}\text { Every } \\
\text { week }\end{array}$ & $\begin{array}{l}\text { Every } \\
\text { month }\end{array}$ & $\begin{array}{l}\text { others will } \\
\text { use }\end{array}$ & $\begin{array}{l}\text { Every } \\
\text { week }\end{array}$ & $\begin{array}{l}\text { Every } \\
\text { month }\end{array}$ & $\begin{array}{c}\text { others will } \\
\text { use }\end{array}$ \\
\hline Definitely bad & 4.4 & 0.0 & 0.0 & 0.5 & 0.0 & 0.0 & 0.8 \\
\hline More bad than good & 6.0 & 0.0 & 0.8 & 1.8 & 0.1 & 0.4 & 1.5 \\
\hline More good than bad & 43.7 & 3.4 & 6.0 & 23.8 & 1.9 & 5.3 & 27.3 \\
\hline Definitely good & 45.9 & 11.5 & 10.1 & 34.8 & 2.2 & 12.8 & 36.6 \\
\hline $\begin{array}{l}\text { Chi-Square } \\
\text { (Significance) }\end{array}$ & & $\begin{array}{c}53.0 \\
(0.000)\end{array}$ & $\begin{array}{c}15.4 \\
(0.002)\end{array}$ & $\begin{array}{c}87.1 \\
(0.000)\end{array}$ & $\begin{array}{c}24.2 \\
(0.000)\end{array}$ & $\begin{array}{c}39.6 \\
(0.000)\end{array}$ & $\begin{array}{c}95.2 \\
(0.000)\end{array}$ \\
\hline
\end{tabular}

\footnotetext{
${ }_{1}^{1}$ BeltLine supporters here are defined as people who think the BeltLine is more good than bad, or it is definitely good. BeltLine skeptics are people who
} think the BeltLine is definitely bad, or it is more bad than good. 
porters are also more optimistic than non-supporters regarding others' use: over $65 \%$ of BeltLine supporters and less than $25 \%$ of Beltline non-supporters think many others will use the BeltLine.

Further, many respondents think that it will not be completed as planned. Two in five respondents indicated their belief that the BeltLine would be smaller or fall far short of current plans. ${ }^{2}$ (the most popular reason given was financial constraints.) Conversely, $18 \%$ predicted it would be larger than planned.

It also bears emphasis that information about the project seems to have no sway over Atlantans' attitudes about the project or expectations about future use. In the survey, half of the respondents were randomly selected to view of a map of the project alongside a short text description; the other half merely saw the text. Visualization and geographic details had no influence on responses, which is all the more remarkable considering how unfamiliar most people are with BeltLine details. Fewer than $10 \%$ of respondents claimed to be already "very familiar" with the project, $29 \%$ said they had not heard of it at all, and $35 \%$ had heard of it but did not know details. Regardless, every variable listed in Table 3 shows no difference in means between those seeing the map and those who did not. It had no influence over support, optimism, expected future use, or beliefs about others using it. ${ }^{3}$

\section{Understanding Public Support and Willingness to Use}

To better understand what explains public support and willingness to use the BeltLine project, a series of ordered logistic regression models are estimated. It can be complicated to sort out all factors that shape and influence public perception and behaviors. In this paper, we follow Kollmuss and Agyeman (2002) and evaluate the impact of demographic factors (education, age, and income), internal (prior knowledge and perception of the city and neighborhood,) and external factors (additional information of the project). We also control for distance, commute time, and current behavioral patterns in our models. Results are presented in Table 5. Model (1) tests who tends to think Beltline is a good idea. The dependent variable measures public support of BeltLine with four ordinally ranked categories ${ }^{4}$ (see variable descriptions in Table 3). Models (2) and (3) test who tends to say they will use BeltLine transit or parks in the future. The ordinal dependent variables measure how often people will use BeltLine transit or parks.

These ordered logit models show some consistent and expected results for support and future use of the BeltLine. The estimated coefficients for distance, optimism about the City's future quality of life, and current park use frequency are significant in all three models. Public support and expectations about future use of BeltLine decline as distance to the BeltLine increases, as people get more pessimistic about Atlanta's quality of life in five years, and as people visit local parks less often. The urban core population appears to support and plan to use the Belthine because of their easy access to its parks and transit. For people who are optimistic of Atlanta's future quality of life, the BeltLine may help realize their vision through economic revitalization and community development. They are more likely to favor the BeltLine, and obtain direct use value from the project. Park lovers might be particularly attracted to the BeltLine because it proposes to transform the city's park system.

Other factors we expect to influence support and future use, however, offer more mixed results. Demographic variables tend to explain expected personal use of BeltLine, but not support. Coefficients for education and age are negative and significant in Model (2) and (3), while coefficients for household income are insignificant in all models. People who are less educated and younger say that they are more likely to use BeltLine parks or transit in the future, although they are not more likely to think the BeltLine is a good idea. Household income has no influence on either support or future use of the Beltline. This may suggest the paradoxical impacts this urban greening initiative has on different income classes. On the one hand, lower income communities may benefit from the affordable housing opportunities provided by the BeltLine. On the other hand, BeltLine is expected to boost property values by making the city more liable and attractive, which potentially invites urban gentrification (Zukin et al., 2009).

Whether or not the BeltLine will catalyze behavioral changes highly depends on people's current lifestyles. Respondents are more likely to use BeltLine parks if they already visit local parks more frequently, and they are more likely to use BeltLine transit if they are already less car-dependent in daily commute. The high toll of daily commuting, one of the major challenges in urban development, is often the result of a city's geographic expansion outstripping its ability to get people moving between home and work (Smith 1990). In this survey, however, time spent in daily commutes plays no role in explaining either public support or use of the BeltLine.

Table 5 results also indicate a nuanced role for attitudes in explaining support and future use. Respondents who hoped that their neighborhood would change express an intent to use the Beltline more but not more support, despite the BeltLine's promise as a catalyst for sustainable urban transformation. Those hoping for neighborhood change tend to embrace behavioral changes to use the BeltLine transit and parks more

\footnotetext{
${ }^{2}$ Apparently, the "first" public opinion poll of 600 City residents was conducted in 2007-two years after the city council approved the TAD-and an "overwhelming majority believe the project will be completed as envisioned." (Atlanta BeltLine, 2013b). That survey predated the Great Recession.

${ }^{3}$ When asking a respondent why they might not use the BeltLine much, one answer category referred to the inconvenient location of the BeltLine. Respondents who saw the map picked this category with the same frequency as those who did not see the map, regardless of their self-reported familiarity with the project.

${ }^{4}$ Responses indicating "I need more information to decide" were dropped from the dataset.
} 
Table 5. Ordered logit regression results for public support and prospective use of the BeltLine.

\begin{tabular}{|c|c|c|c|}
\hline \multirow[b]{2}{*}{ Variable } & \multirow[b]{2}{*}{ Public Support } & \multicolumn{2}{|c|}{ Prospective Use } \\
\hline & & Transit & Park \\
\hline Education & -0.025 & $-0.065^{*}$ & -0.066 \\
\hline Age & -0.0013 & $-0.021 * * *$ & $-0.021 * * *$ \\
\hline Household income & -0.062 & 0.089 & 0.052 \\
\hline Familiarity & -0.015 & $0.20 * *$ & $0.27 * * *$ \\
\hline Map & -0.22 & 0.069 & -0.056 \\
\hline Distance & $-0.22 * *$ & $-0.31 * * *$ & $-0.37 * * *$ \\
\hline Map*Distance & 0.067 & 0.068 & -0.012 \\
\hline Commute time & -0.0027 & 0.0026 & 0.0021 \\
\hline Hoped my neighborhood would change & 0.035 & $0.42 * * *$ & $0.26 * *$ \\
\hline Atlanta quality of life improving in 5 years & $0.48 * * *$ & $0.21^{* *}$ & $0.34 * * *$ \\
\hline Commute mode (2) & 0.24 & $-0.59 * * *$ & -0.27 \\
\hline Park use frequency (3) & $0.31 * * *$ & $0.43 * * *$ & $0.72 * * *$ \\
\hline $\mathbf{N}$ & 548 & 657 & 654 \\
\hline Log Likelihood & -543.07 & -765.86 & -688.24 \\
\hline
\end{tabular}

${ }^{*} \mathrm{p}<0.1 ;{ }^{* *} \mathrm{p}<0.05 ;{ }^{* * *} \mathrm{p}<0.01$

(1) Prospective use of BeltLine parks ("How would you use the BeltLine park and trails, supposing the project is completed as planned?"), coded per the answer categories: I would visit BeltLine parks or trails several times per week (3), per month (2), per year (1), or never (0).

(2) Commute mode is a binary variable, coded as 1 if the response is I drive alone and coded as 0 otherwise.

(3) Park use frequency ("How often do you visit local or city parks?"), coded per the answer categories: Once per week or more (4), at least once per month (3), at least once per year (2), less than yearly (1), never (0).

frequently. Conversely, those content with their neighborhood as-is intend to use the Beltline less and are just as likely to support the BeltLine, perhaps because they see its transformation as affecting others' neighborhoods. Again, the BeltLine has broad appeal by offering a chance for others to change.

Geographic information and prior knowledge of the project play different roles here. Familiarity is positive and significant in Model (2) and (3). People are more likely to plan to use BeltLine parks or transit more if they are more familiar with the project. Familiarity, however, does not necessarily enhance public support of the BeltLine. Surprisingly, visualization and geographic details about the project have virtually no impact on attitudes about the project or prospective use-even though most respondents would be hard pressed to describe its proposed location. ${ }^{5}$ Public support appears unrelated to familiarity with and information about the project-casting doubt on the political relevance of a well-informed population. And while familiarity does predict greater intent to use the BeltLine, the (randomly assigned) information treatment in survey was insufficient to affect prospective use responses. The coefficients for the map variable and the interaction term between map and distance are all insignificant. Proximity to the Belt-
Line is associated with more support and intended use, above and beyond self-reported familiarity, but these proximity effects are neither stronger nor weaker when respondents are primed or reminded about the exact location of the BeltLine.

\section{Discussion and Conclusions}

This study identifies the potential gap between public support and use of sustainable urban project using data from a survey of the general public. We focus on the Atlanta BeltLine project, one of the largest urban greening initiatives in the country involving a mix of sustainable transportation, greenspace, and economic revitalization projects.

Overall, the survey reveals a seeming contradiction between two distinct perspectives each respondent might take: thinking as citizens, as members of the public, and thinking as consumers, engaged in private behavior aimed at maximizing satisfaction (Sagoff, 2007). When asked to think as citizens about what is best for the community, most respondents support adopting some or all BeltLine components. When asked to think about their own behavior, as self-interested individuals, they show little intent to use the infrastructure personally.

\footnotetext{
${ }^{5}$ Pre-testing of the survey instrument revealed a common misperception that the BeltLine was outside Atlanta's perimeter highway, rather than in the urban core.
} 
The results also show that drivers of public support for the urban infrastructure project and behavioral changes differ in important ways. BeltLine supporters and users tend to live in the urban core, use local parks often, and be optimistic about the city's future quality of life. Education, age, familiarity, and hopes for neighborhood change have no impact on public support, but they do affect individual willingness to use the Beltline. In addition, sustaining behavioral responses to the BeltLine is strongly correlated with people's current usage of parks and non-automobile transportation options. Those indicating greater expected behavioral changes are those whose current behavior already appears to be more sustainable. Reaching certain skeptics or potential users may be a challenge for planners designing solutions, and the results here indicate which groups to target.

A further wrinkle arises in that many respondents do expect others to adopt the BeltLine, though they themselves do not, while at the same time they suspect others do not favor it, though they themselves do. ${ }^{6}$ The implications of this particular finding are best left to another context.

In order to interpret these findings, we need to understand not only how this contradiction arises, but how it is that the contradiction appears so explicitly in responses to the survey. If we are correct in thinking that the tension between public support and private behavior is largely a function of the stickiness of social and technological systems, then how is it that people living within and conditioned by those systems are able to see beyond them enough to grasp and even support the transformative vision of the BeltLine project?

One possible explanation is that the survey questions are hypothetical. When engaged in blue-sky thinking about what might be possible, talk is cheap (Jerolmack \& Khan, 2014). Liking the idea of the BeltLine, especially as a direction for the city to go, need not imply that individuals would be willing to sacrifice and change for it, or even that they could imagine the possibility of changing their own private conduct, given the external and internal constraints under which they operate within the dominant urban form.

Put in different terms, there is no opportunity cost for expressing support for the BeltLine project in a hypothetical survey. The project's primary funding mechanisms (i.e., TIF) played into this with a bold promise and little apparent sacrifice. Making real changes entailed in using the BeltLine are not so cheap, however, as it may involve moving to a new residence, changing employment, changing commuting patterns and modes, and other changes that involve not only new costs, but perhaps the sacrifice of costs already sunk in the status quo. In a recent referendum on a sales tax earmarked for Atlanta regional transportation projects, we saw far less support for paying for projects like this (Hart, 2012) than for its abstract vision in the survey. When the lunches are not so free, the jewels in its emerald necklace shine a bit less bright.
Another possible explanation as to why the contradiction would appear so starkly in the survey is a "sustainability for thee" impetus (Kalamas, Cleveland, \& Laroche, 2014). Respondents seemed eager to advocate for a systemic remedy, constructing the BeltLine, especially insofar as it transformed others' behavior while leaving their own neighborhood, attitudes, and patterns of living unchanged. Unlike Atlanta's newcomers, the bulk of Atlantans appear well-entrenched-stuck-in their city and their ways. They might welcome the BeltLine as an attempt to dislodge the city and get others to live sustainably, if only so there will be fewer cars on the highway as they drive to work. But they do not envision substantial change on their part. When such perspectives are pervasive, the city may find itself buying smart solutions that attract few users.

This analysis is not without limitations. First of all, the unique nature of the BeltLine project and the online nature of the survey (and its attendant response rate challenges) can limit generalizability of these results. Second, constraints in survey administration lead to a limited set of measures. Variables such as race, occupation and workplace location, and other social factors can be particularly interesting for future research to understand certain populations. Third, far more could be done to examine the role of knowledge about the project in affecting public support and attitudes. Fourth, the survey context limits how deeply we can probe into reasons underlying the divergence between support and prospective use. While the results here illustrate the different factors influencing each, additional research is needed to provide a richer description. Another concern common to surveys like this is social desirability bias. Yet because both support and prospective use may be pro-social choices, the divergence in responses is harder to reconcile with social desirability. Lastly, given the significance of the BeltLine to the region, we sampled the whole metropolitan Atlanta area. Despite oversampling within city limits, the sample may not be representative of the urban core. A narrower conception of the BeltLine might concentrate on certain communities targeted or served by the project rather than a more general public. Private choices and public support among certain groups (e.g., minorities, TAD residents, housing developers) warrant their own focused studies.

The Belttine experience thus far has several lessons for other sustainable urban projects. First, although the political and popular demands for much of the project are sufficient to permit some progress despite the Great Recession, sustainable transformation of the city may still be far away if the behavior of individuals is still caught up in the patterns, attitudes and values of the dominant urban form. People's lack of interest in using the BeltLine parks and transit signals that advocates for the BeltLine have not yet grappled with this most basic problem.

A promising approach to addressing the problem would be to approach sustainable urban infrastructure

\footnotetext{
${ }^{6}$ While $73 \%$ favored the BeltLine themselves, only $22 \%$ believed that others think the BeltLine is a good idea.
} 
planning as an adaptive, participatory process in which technical innovation, policy change, public engagement, and cultural transformation are all in play. Stakeholder engagement-really, engaging the public in a wideranging conversation about our shared environmentis a critical part (Morrissey, Iyer-Raniga, McLaughlin, \& Mills, 2012). Innovative approaches may be used to effectively engage different groups of citizens in urban planning, design, and implementation.

Empirical studies have shown the potential of internet-based participation tools in alleviating unequal power relation and providing an interactive and networked environment for urban planning decision making. Web-based virtual worlds, such as Facebook and Second Life can provide platforms for online community organizing around planning issues and virtual workshops (EvansCowley \& Hollander, 2010). In the case of the BeltLine, online surveys can be used to identify different public groups, and understand the reasons that keep them from using the BeltLine. Citywide briefings, email distribution lists, and e-newsletters can be created around issue topics to target specific group of people. Other smart, sustainable urban projects would do well to go beyond building political support for technical projects toward the development of a new, shared vision of the built environment, its meaning, and its value.

Second, the fiction of a free lunch underlines much of the disjoint between the project's ambitions and its present reality. We cannot take for granted that strong political support for smart infrastructure is sufficient if private behavioral/usage decisions are then going to be necessary for the initiative to succeed. For urban planners, the design, adoption and implementation of smart solutions should be guided by the goal of shifting to sustainable behavioral changes or helping residents become "stuck" in more sustainable ways (Kirkman et al., 2012). The interplay between systemic constraints, private choices, and public support suggests that private adoption decisions may not follow until and unless the systems in which they are embedded are already changing. Thus, efforts to bring about smart and sustainable urban infrastructure may face something of a bootstrapping problem.

Third, the project's most politically controversial component-transit-is also the part that represents the greatest long-term commitment to a new and sustainable city. Unsurprisingly, committing Atlanta to a new vision is contentious. Even among supporters, it seems hard to imagine self-sacrifice for its unrealized promise. If they build it, will Atlantans come? Project planners are banking on "yes."

Alternatively cast, however, the better question is: "What do Atlantans want to get stuck with?" Other smart solutions encounter these questions as well. Sticky equilibria in urban forms exist for powerful reasons (and the alternative of an unstable urban form is even harder to imagine than an Atlanta with greater density and transit). Perhaps it is here where the debate should be had, and cultivated, around the question of what we want to get stuck with. When windows of opportunity open, as they seem to have for the Beltline, the question is no longer idle. Future generations will enjoy and suffer today's answer. If being stuck with something is inevitable, or at least desirable, then acknowledging that helps frame the terms of the discussion and puts the onus on the planning process to objectively cultivate public imaginations about those future states. In this regard, participatory urban planning from early stages may influence how well infrastructure projects ultimately impact sustainable behavioral patterns after project implementation. This can be a fruitful area for future research.

\section{Acknowledgments}

The initial data gathering of this research was funded by the National Science Foundation, Ethics and Values Studies, Award ID 0646739, "Stuck With the Dominant Urban Form? Ethics, Technology, and the Built Environment." Any opinions, findings, and conclusions or recommendations expressed in this material are those of the authors and do not necessarily reflect the views of the National Science Foundation.

\section{Conflict of Interests}

The authors declare no conflict of interests.

\section{References}

Alberti, M. (1996). Measuring urban sustainability. Environmental Impact Assessment Review, 16(4/6), 381424. doi:10.1016/S0195-9255(96)00083-2

Alex Garvin \& Associates, Inc. (2004). The Beltline emerald necklace: Atlanta's new public realm. Atlanta, GA: The Trust of Public Land. Retrieved from http://beltline.org/wp-content/uploads/2012/ 04/Emerald-Necklace-Study1.pdf

Angel, S., Parent, J., Civco, D. L., Blei, A., \& Potere, D. (2011). The dimensions of global urban expansion: Estimates and projections for all countries, 2000-2050. Progress in Planning, 75(2), 53-107. doi:10.1016/j.progress.2011.04.001

Arrington, G. B., \& Cervero, R. (2008). Effects of TOD on housing, parking, and travel (TCRP Report 128). Washington, DC: Transportation Research Board of the National Academies.

Atlanta BeltLine. (2011). Mayor Reed to lead official dedication of Historic Fourth Ward Park. Atlanta BeltLine. Retrieved from http://beltline.org/ 2011/06/16/mayor-reed-to-lead-official-dedicationof-historic-fourth-ward-park/

Atlanta BeltLine. (2013a). Atlanta BeltLine-2030 strategic implementation plan final report. Atlanta, GA: Atlanta BeltLine. Retrieved from https://beltlineorgwpengine.netdna-ssl.com/wp-content/uploads/2013 /03/Beltline_Implementation-Plan_web.pdf 
Atlanta BeltLine. (2013b). Project history. Atlanta BeltLine. Retrieved from http://beltline.org/progress/ progress/project-history/ Atlanta, GA. Atlanta BeltLine.

Atlanta BeltLine. (2017a). The blueprint for the Atlanta BeltLine. Atlanta Beltline. Retrieved from http:// beltline.org/progress/planning/master-planning/

Atlanta BeltLine. (2017b). The project overview, planning, progress \& engage. Atlanta BeltLine. Retrieved from http://beltline.org/progress/progress/

Atlanta BeltLine. (2017c). Atlanta BeltLine overview: The Atlanta BeltLine in 5. Atlanta BeltLine. Retrieved from http://beltline.org/about/the-atlanta-beltlineproject/atlanta-beltline-overview/

Atlanta BeltLine Tax Allocation District Advisory Committee. (2012). Atlanta Beltline five year work plan 2006-2010 review. Atlanta, GA: Atlanta BeltLine. Retrieved from http://saportareport.com/wp-content/ uploads/Five-Year-Work-Plan-Review-2-12-12.final_. pdf

Atlanta Development Authority. (2006). Atlanta BeltLine project: Plan of work for 2006-2010 budget. Atlanta, GA: Atlanta Development Authority.

Bijker, W. E. (1997). Of bicycles, bakelites, and bulbs: Toward a theory of sociotechnical change. Cambridge, MA: MIT Press.

Borén, S., Nurhadi, L., Ny, H., Robèrt, K. H., Broman, G., \& Trygg, L. (2017). A strategic approach to sustainable transport system development-Part 2: The case of a vision for electric vehicle systems in southeast Sweden. Journal of Cleaner Production, 140, 62-71. doi:10.1016/j.jclepro.2016.02.055

Bulkeley, H., \& Betsill, M. (2005). Rethinking sustainable cities: Multilevel governance and the 'urban' politics of climate change. Environmental Politics, 14(1), 42-63. doi:10.1080/0964401042000310178

Camagni, R., Capello, R., \& Nijkamp, P. (1998). Towards sustainable city policy: An economy-environment technology nexus. Ecological Economics, 24(1), 103-118. doi:10.1016/S0921-8009(97)00032-3

Cavallaro, K. (2012). Revealing the answer to life's most difficult market research question: Why don't people join panels? (Survey Sampling International white paper). Shelton, CT: SSI. Retrieved from http://www.dgof.de/wp-content/uploads/2012/07/ WP_Why-Dont-people-Join-Panels.pdf

Cervero, R. (1993). Ridership impacts of transit-focused development in California. Berkeley, CA: Institute of Urban and Regional Development.

Drazkiewicz, A., Challies, E., \& Newig, J. (2015). Public participation and local environmental planning: Testing factors influencing decision quality and implementation in four case studies from Germany. Land Use Policy, 46, 211-222. doi:10.1016/ j.landusepol.2015.02.010

Durand, C. P., Andalib, M., Dunton, G. F., Wolch, J., \& Pentz, M. A. (2011). A systematic review of built environment factors related to physical activity and obe- sity risk: Implications for smart growth urban planning. Obesity Reviews, 12(5). doi:10.1111/j.1467789X.2010.00826.x

Environmental Protection Agency. (2017). About smart growth. Washington, DC: EPA. Retrieved from https:// www.epa.gov/smartgrowth/about-smart-growth

Evans-Cowley, J., \& Hollander, J. (2010). The new generation of public participation: Internet-based participation tools. Planning Practice \& Research, 25(3), 397-408. doi:10.1080/02697459.2010.503432

Fiksel, J. (2006). Sustainability and resilience: Toward a systems approach. Sustainability: Science, Practice, \& Policy, 2(2).

Florida, R., Mellander, C., \& Rentfrow, P. J. (2013). The happiness of cities. Regional Studies, 47(4), 613-627. doi:10.1080/00343404.2011.589830

Gigliotti, L. M. (1992). Environmental attitudes: 20 years of change?. The Journal of Environmental Education 24(1), 15-26. doi:10.1080/00958964.1992.9943491

Grimm, N. B., Faeth, S. H., Golubiewski, N. E., Redman, C. L., Wu, J., Bai, X., \& Briggs, J. M. (2008). Global change and the ecology of cities. Science, 319(5864), 756-760. doi:10.1126/science.1150195

Hart, A. (2012). Voters reject transportation tax. The Atlanta Journal-Constitution. Retrieved from http:// www.ajc.com/news/news/state-regional-govt-politics /voters-reject-transportation-tax/nQXfq

Herring, H., \& Roy, R. (2007). Technological innovation, energy efficient design and the rebound effect. Technovation, 27(4), 194-203. doi:10.1016/ j.technovation.2006.11.004

Hodson, M., \& Marvin, S. (2010). Can cities shape sociotechnical transitions and how would we know if they were?. Research policy, 39(4), 477-485. doi:10.1016/ j.respol.2010.01.020

Hodson, M., Marvin, S., Robinson, B., \& Swilling, M. (2012). Reshaping urban infrastructure. Journal of Industrial Ecology, 16(6), 789-800. doi:10.1111/j.15309290.2012.00559.x

Hughes, T. P. (1987). The evolution of large technical systems. In W. Bijker, T. Hughes, \& T. Pinch (Eds.), Social construction of technological systems: New directions in the sociology and history of technology (pp. 51-82). Cambridge, MA: MIT Press.

Hughes, T. P. (1994). Technological momentum. In M. R. Smith \& L. Marx (Eds.), Does technology drive history? The dilemma of technological determinism (pp. 101-113). Cambridge, MA: MIT Press.

Jerolmack, C., \& Khan, S. (2014). Talk is cheap: Ethnography and the attitudinal fallacy. Sociological Methods \& Research, 43(2), 178-209. doi:10.1177/ 0049124114523396

Kaika, M., \& Swyngedouw, E. (2000). Fetishizing the modern city: The phantasmagoria of urban technological networks. International Journal of Urban and Regional Research, 24(1), 120-138. doi:10.1111/14682427.00239

Kalamas, M., Cleveland, M., \& Laroche, M. (2014). Pro- 
environmental behaviors for thee but not for me: Green giants, green Gods, and external environmental locus of control. Journal of Business Research, 67(2), 12-22. doi:10.1016/j.jbusres.2013.03.007

Kemp, R., Schot, J., \& Hoogma, R. (1998). Regime shifts to sustainability through processes of niche formation: The approach of strategic niche management. Technology Analysis \& Strategic Management, 10(2), 175-198. doi:10.1080/09537329808524310

Khansari, N., Mostashari, A., \& Mansouri, M. (2014). Impacting sustainable behavior and planning in smart city. International Journal of Sustainable Land Use and Urban Planning, 1(2), 44-61.

Kirkman, R., Noonan, D. S., \& Dunn, S. K. (2012). Urban transformation and individual responsibility: The Atlanta BeltLine. Planning Theory, 11(4), 418-434. doi:10.1177/1473095212442821

Kollmuss, A., \& Agyeman, J. (2002). Mind the gap: Why do people act environmentally and what are the barriers to pro-environmental behavior?. Environmental Education Research, 8(3), 239-260. doi:10.1080/ 13504620220145401

Kramers, A., Höjer, M., Lövehagen, N., \& Wangel, J. (2014). Smart sustainable cities-Exploring ICT solutions for reduced energy use in cities. Environmental Modelling \& Software, 56, 52-62. doi:10.1016/ j.envsoft.2013.12.019

Kumar, A. (1990). Impact of technological developments on urban form and travel behaviour. Regional Studies, 24(2), 137-148. doi:10.1080/ 00343409012331345854

Loo, B. P., Chen, C., \& Chan, E. T. (2010). Rail-based transit-oriented development: Lessons from New York City and Hong Kong. Landscape and Urban Planning, 97(3), 202-212. doi:10.1016/j.landurbplan. 2010.06.002

Monstadt, J. (2009). Conceptualizing the political ecology of urban infrastructures: Insights from technology and urban studies. Environment and Planning $A$, 41(8), 1924-1942. doi:10.1068/a4145

Morrissey, J., Iyer-Raniga, U., McLaughlin, P., \& Mills, A. (2012). A strategic project appraisal framework for ecologically sustainable urban infrastructure. Environmental Impact Assessment Review, 33(1), 55-65. doi:10.1016/j.eiar.2011.10.005

Nam, T., \& Pardo, T. A. (2011). Conceptualizing smart city with dimensions of technology, people, and institutions. In Proceedings of the 12th annual international digital government research conference: digital government innovation in challenging times (pp. 282-291). New York: ACM.

Nasri, A., \& Zhang, L. (2012). Impact of metropolitanlevel built environment on travel behavior. Transportation Research Record: Journal of the Transportation Research Board, (2323), 75-79. doi:10.3141/ 2323-09
Nasri, A., \& Zhang, L. (2014). The analysis of transitoriented development (TOD) in Washington, DC and Baltimore metropolitan areas. Transport Policy, 32, 172-179. doi:10.1016/j.tranpol.2013.12.009

Nevens, F., Frantzeskaki, N., Gorissen, L., \& Loorbach, D. (2013). Urban transition labs: Co-creating transformative action for sustainable cities. Journal of Cleaner Production, 50, 111-122. doi:10.1016/ j.jclepro.2012.12.001

Nielsen, S. B., \& Elle, M. (2000). Assessing the potential for change in urban infrastructure systems. Environmental Impact Assessment Review, 20(3), 403-412. doi:10.1016/S0195-9255(00)00051-2

Pendergrast, M. (2017). City on the verge: Atlanta and the fight for America's urban future. New York: Basic Books.

Pucher, J. (1988). Urban travel behavior as the outcome of public policy: The example of modal-split in Western Europe and North America. Journal of the American Planning Association, 54(4), 509-520. doi:10.1080/01944368808976677

Sagoff, M. (2007). The economy of the earth: Philosophy, law, and the environment. Cambridge, UK: Cambridge University Press.

Sahely, H. R., Kennedy, C. A., \& Adams, B. J. (2005). Developing sustainability criteria for urban infrastructure systems. Canadian Journal of Civil Engineering, 32(1), 72-85. doi:10.1139/104-072

Seto, K. C., \& Shepherd, J. M. (2009). Global urban land-use trends and climate impacts. Current Opinion in Environmental Sustainability, 1(1), 89-95. doi:10.1016/j.cosust.2009.07.012

Sherman v. Atlanta Independent School System et al. 744 S.E.2d 26 (Ga. 2013).

Smith, N. (1990). Uneven development: Nature, capital, and the production of space. Oxford: Basil Blackwell.

Stieninger, P. (2013). Changing human behavior towards energy saving through urban planning: Creation of a new planning approach. Lessons learned from Europe and North America. Saarbrücken: Lambert Academic Publishing.

Tumlin, J., Millard-Ball, A., Zucker, C., \& Siegman, P. (2003). How to make transit-oriented development work. Planning, 69(5), 14-14.

U.S. Census Bureau. (2016). Annual estimates of the resident population: April 1, 2010 to July 1, 2015. Suitland, MD: U.S. Census Bureau.

Wheeler, S. M. (2003). The evolution of urban form in Portland and Toronto: Implications for sustainability planning. Local Environment, 8(3), 317-336. doi:10.1080/13549830306656

Zukin, S., Trujillo, V., Frase, P., Jackson, D., Recuber, T., \& Walker, A. (2009). New retail capital and neighborhood change: Boutiques and gentrification in New York City. City \& Community, 8(1), 47-64. doi:10.1111/j.1540-6040.2009.01269.x 


\section{COGITATIO}

\section{About the Authors}

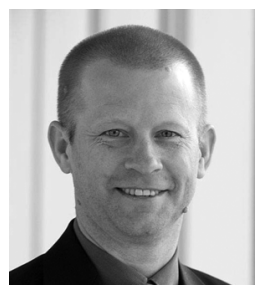

Douglas Noonan is Professor of Public and Environmental Affairs at SPEA. His research focuses on a variety of policy and economics issues related to the urban environment, neighborhood dynamics, and quality-of-life. His research has been funded by a variety of organizations (e.g., National Science Foundation, Environmental Protection Agency, National Endowment for the Arts) on topics like environmental risks, energy, air quality, green urban revitalizations, and cultural economics. Noonan earned his Ph.D. in Public Policy at the University of Chicago.

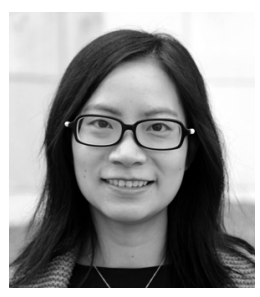

Shan Zhou obtained her PhD in Public Policy from Georgia Institute of Technology. Her research focuses on environmental and energy policy, sustainability and clean technology deployment. She publishes in both policy-oriented and interdisciplinary journals, such as Review of Policy Research, Journal of Cleaner Production and Wiley Interdisciplinary Reviews: Energy and Environment.

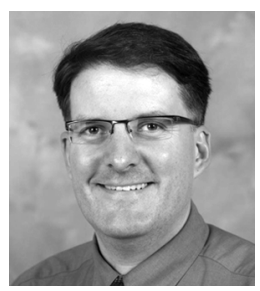

Robert Kirkman is Associate Professor in the School of Public Policy at the Georgia Institute of Technology. His focus is in practical ethics, including ethics of the built environment, engineering ethics, and ethics education. 